\title{
地震入力に対してロバスト性のある免震構造に関する研究 \\ A STUDY ON SEISMIC ISOLATION SYSTEM WITH ROBUSTNESS FOR INCREASING GROUND MOTION LEVEL
}

\author{
東野雅彦*, 和田 章** \\ Masahiko HIGASHINO and Akira WADA
}

\begin{abstract}
The development of seismology and recent observation records have been evolving the ground motions to be considered in structural engineering. The future research will seems to require quite an amount of revisions in ground motions. Since it is difficult to envisage the goal of seismology, some measures to deal with increasing levels of ground motions must be included in structural engineering. Consideration of excessive strength in structural engineering is not economical. However, making extra margin in sliding bearings for seismic isolation devices require less expenditures in structural design. The authors have conducted analytical study of this kind of system and have confirmed the sliding isolation system has the potential to keep isolation characteristics for large input ground motion level. However, the maximum displacement and residual displacement become quite large, especially when the elements to provide restoring force are not employed, it was over $1.0 \mathrm{~m}$. The authors think this level of displacement can be considered in the structural design of foundations to withstand P-Delta effect by building weight. From this study, the authors concluded that if the foundations are well designed to accept P-Delta moment in isolation interface, sliding bearings can be a potential candidate to provide robustness to deal with excessive level of input ground motions.
\end{abstract}

Keywords : Seismic isolation, Input ground motion level, Sliding bearing, Robustness, Parametric study, Residual displacement, Rotational response

免震, 入力レベル, 滑り支承, ロバスト性, 圥長性、パラメトリックスタディ、残留変形, ねじれ応答

\section{1. 序論}

近年の免震構造や制震構造を含む耐震設計技術の発達により建築 構造物の安全性は飛躍的に高まってきている。その一方で、地震観 測技術の発達や地震動研究の進歩により、耐震設計上考慮すべき地 震入力レベルや周期帯域も拡大寸る必要があることも明らかにされ つつある。構造物の耐震設計は設定された設計用入力地震動スペク トルに灾じて実施される。したがって、設計用入力スペクトルが変 更されると、設計も異なったものになる。これは、たとえ制震構造 や免震構造を導入した場合でも同様である。地震観測技術や地震動 研究はこれからも更なる発展が期待されるため、今後設計用入力地 震動スペクトルは更なる変更が加えられると考えて間違いない。し かし、入力地震動によ゙こまで変更が導入されるか、現時点で上限を 予測することは不可能である。建築構造物は一度施工されると短く ても数十年は使用される。建築規模が大きくなるほど使用年数は長 くなり、100 年以上建物が使用されることも構造設計上想定してお く必要があるが、現在行われている設計ではこの様な入力の増加ま で考慮したロバスト性、或いは圥長性のある設計は経済的問題もあ り事実上あまり行われていない。
構造物の冗長性に関寸る研究は、予想外の外乱や偶発的荷重、或 いは設計、施工上のミス等により架構中の部材が損傷したり久落し た場合に対し、架構の鉛直荷重と水平荷重に対寸る荷重支持性能に 関する研究が数多く行われている。和田等は立体トラス構造の部材 の久落に対する咒長性の検討を行い 1)、伊藤等はラーメン構造の鉛 直部材の欠落に対寸る架構の圥長性の検討を行っている3)。また、 伊山等は想定を上回る地震荷重を受けてブレースが破断して残され る、接点が岡接されているラーメン構造における耐震朵長性の検討 を行っている 2)。一方、竹脇は超高層免震建物における粘性減衰夕゙ ンパーの役割を建物高さをパラメータにとり検討を行い、構造性能 のロバスト性に対する影響を検討している 17$) 。$

構造部材の変形性能や耐力に余裕を持たせることは設計上可能で あるが、法律で規定されていない未知のレベルまで入力を考慮する ことは必ずしも経済的な設計とは言えない。その中にあって免震構 造では、基本的に免震装置に圥長性を持たせることのみで過大な入 カレベルに対応することができる。この点に着目し、本研究では近 年観測された入力地震動や大きな入力レベルの地震動が作用した時 の免震構造の応答解析結果から免震構造におけるロバスト性付与の 可能性を探る。
* (株)竹中工務店技術研究所 マネージャー・工修

** 東京工業大学建築物理研究センター 教授·工博
General Manager, Takenaka R\&D Institute

Prof., Structural Engineering Research Center, Tokyo Institute of Technology, Dr. Eng. 
入力を決定する要素は以下の項目が挙げられる。

a ）周期、b ）レベル、c）継続時間、d）繰り返し（余震） これらに対して免震構造にロバスト性を持たせる手段として用いら れる一般的手法は減衰を付与寸る方法で、その特徴は以下があげら れる。

1）周期特性に対して鈍感にできる。

2) 粘性減衰は入力エネルギーの増大に対して安定したエネルギ 一吸収が期待できるが、履歴減衰の場合は応答変位が増大し ても耐力は一定のままであるため、系全体の等価減衰量は減 少する。何れの場合でも、過度な減衰増大は加速度応答を増 大する。

3 ） 継続時間の増大に対して粘性減衰は熱の問題があり、履歴減 衰は疲労の問題がある。

4）粘性減衰は残留変位が無く、余震に対して堅牢であるが、履 歴減衰は残留変位量が問題となる。

ロバスト性付与の手段として滑り支承を採用した場合、以下の特徵 が挙げられる。

1）復元力を減らすことにより周期特性に対して鈍感にできる。

2）変形可能範囲を大きくとることにより、入力レベルの増大に 対応できる。

3) 継続時間の増大による滑り面の摩擦熱の検討が必要。

4 ）残留変位量の評価が必要。

地震動の入力レベルと周期特性の不確定性に対し、滑り支承は水 平変形性能によりロバスト性の付与が可能であり、この点が有利で あるため本研究では滑り支承に関する研究を行う事とした。しかし、 滑り支承は残留変位の問題があることから、本研究ではこの点を含 めた検討を行う。

滑り支承に関するこれまでの研究は、装置の形態として平面滑り 支承と球面滑り支承、所謂 FPS (Friction Pendulum System) 4) に分けられる。本検討は滑り支承を用いて水平変形性能を増大させ ることを目的としているため、平面滑りを検討対象とする。平面滑 り支承に関するこれまでの研究は大きく分けて 3 種類の検討がなさ れてきている。即ち、滑り支承自体の力学的性能の解明、滑り支承 の解析モデルの研究、および実験的、および解析的な滑り免震構造 の地震応答性状の研究である。本検討は、滑り免震構造の地震応答 性状の検討に当たる。

まず、滑り支承の力学性状の研究では摩擦係数の面圧依存性と速 度依存性の評価 ${ }^{5)-8}$ )、および静止摩擦係数と動摩擦係数の違い等の 評価に関する研究 9)が行われている。本検討では簡単のために、摩 擦係数の各依存性と静止摩擦係数は無視し、一定の動摩擦係数とし て検討を行う。解析モデルに関する研究は、剛滑り支承のモデル化 において、固着状態と動いた状態への切り替え方法 10$), 11$ や急激な摩 擦力の発生とその解放に伴う不釣り合い力の効果的処理方法 ${ }^{6) な と ゙ ~}$ が検討されている。その一方で、完全弾塑性型のバイリニアモデル を用いた検討 12 ) も評価の方法として広く使われている。本検討では 1 質点モデルの解析に始まり、多質点モデルの解析と据り応答の評 価も行うこと。および、応答評価は最大応答量と残留変形量に注目 し、応答波形の正確さは本検討の目的においてはそれほど精度を要 求しないことから、汎用ソフトを用い完全弾塑性型のバイリニアモ デルを用いることとした。
滑り免震構造の応答に関する研究は 1 質点応答解析による数例の

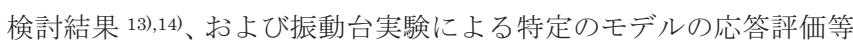
15) は報告されているが、解析と実験何れの場合にも、パラメータを 多く採り応答性状を体系的に評価した例はあまりない。その中で、 千葉等はエネルギーの釣り合いに基づく応答予測法を提案し、各種 応答結果を提示しているが、免震構造全般を対象とした検討のため 滑り免震の応答評価に関しては提案された応答評価法によるより、 直接的な応答解析が適している。また、小出等は 1 質点系の応答解 析で $0.5 \mathrm{~m} / \mathrm{s}$ の入力レベルに対して応答加速度と応答変位のバラン ス点として、摩擦係数 0.05 を得ている ${ }^{18)}$ 。

本検討は、汎用解析ソフト 16)を用い時刻歴応答解析を行うことに より、1 質点、多質点、および支承が平面的に広がりを持って配置 された場合の据れ応答量の評価を行い、滑り支承を用いた場合の免 震構造のロバスト性の付与の可能性について検討する。

\section{2.一質点および多質点解析モデル}

本検討に用いる建物モデルを図 1 に示す。この建物は実際に設計 施工された建物をベースにしている ${ }^{6)}$ 。この建物は RC 構造 3 層で あり、4 質点にモデル化した上部架構の諸元を表 1 に示す。上部構 造の復元力特性はトリリニアー型とし、履歴ループは原点指向型を 採用した。粘性減衰は 1 次モードに対して $2 \%$ の減衰となるように 各階にダンパーを配置した。1 質点モデルにおいては各階の質量を 総和し、 $3.11 \times 10^{6} \mathrm{~kg}$ を質量として解析を行った。

免震装置の平面配置を図 2 に示す。据じれ応答解析以外では免震 装置の特性を集約した。図 3 に ( 1 ) 復元力付き弾性滑り支承と (2) 復元力付き剛滑り支承の概念図を示す。各要素の解析モデルを図 4 に示す。(1) に示す弾性滑りモデルは、実際の設計で用いられてい る市販の弾性滑り支承で採用されているものをモデル化した。（2） を剛滑り支承の復元力として採用した。付録に示寸検討に基づき解 が安定する範囲で最も高い初期剛性を選んだ。また、実際の滑り支 承は静止摩擦係数を含夕、動きだしの部分でピーク状の高い摩擦力 を発生させる材料が多い。本来静止摩擦を含む検討とする心゙きであ るが、静止摩擦力の評価は複雑であるため、本検討ではまず動摩擦 に限定した検討とした。（3）は剛滑りモデルにおいて 2 次勾配を 35 秒の周期の非常に緩い剛性を採用した中間モデルとした。何れも 履歴ループはノーマルバイリニアとした。(4) に復元力要素として

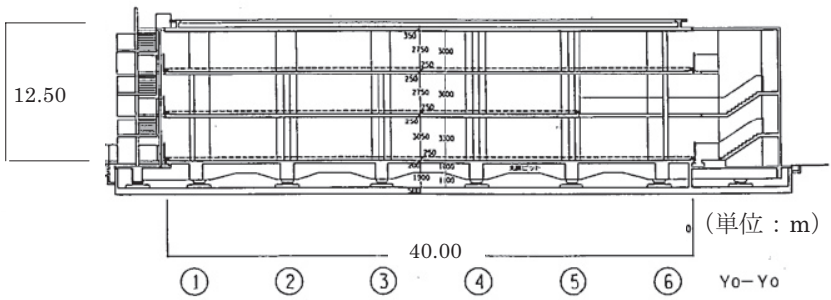

図 1 検討対象建物モデル

表 1 上部構造諸元

\begin{tabular}{ccccccccc}
\hline 階 & $\begin{array}{c}\text { 階高 } \\
(\mathrm{m})\end{array}$ & $\begin{array}{c}\text { 質量 } \\
(\mathrm{kg})\end{array}$ & $\begin{array}{c}\text { 初期剛性 } \\
(\mathrm{kN} / \mathrm{m})\end{array}$ & $\begin{array}{c}\text { 第1折点 } \\
\text { 耐力 }(\mathrm{kN})\end{array}$ & $\begin{array}{c}\text { 第2折点 } \\
\text { 耐力 }(\mathrm{kN})\end{array}$ & $\begin{array}{c}\text { 第2剛性 } \\
\text { 低下率 }\end{array}$ & $\begin{array}{c}\text { 第3剛性 } \\
\text { 低下率 }\end{array}$ & $\begin{array}{c}\text { 減衰係数 } \\
(\mathrm{kNs} / \mathrm{m})\end{array}$ \\
\hline \hline $\mathrm{R}$ & & $7.95 \times 10^{5}$ & - & - & - & - & - & - \\
3 & 3.30 & $6.91 \times 10^{5}$ & $9.13 \times 10^{5}$ & 1635 & 5232 & 0.345 & 0.156 & 1891 \\
2 & 3.25 & $6.21 \times 10^{5}$ & $1.16 \times 10^{6}$ & 2190 & 7011 & 0.444 & 0.208 & 2401 \\
1 & 4.00 & $1.00 \times 10^{6}$ & $1.65 \times 10^{6}$ & 2368 & 7576 & 0.357 & 0.123 & 3430 \\
\hline
\end{tabular}




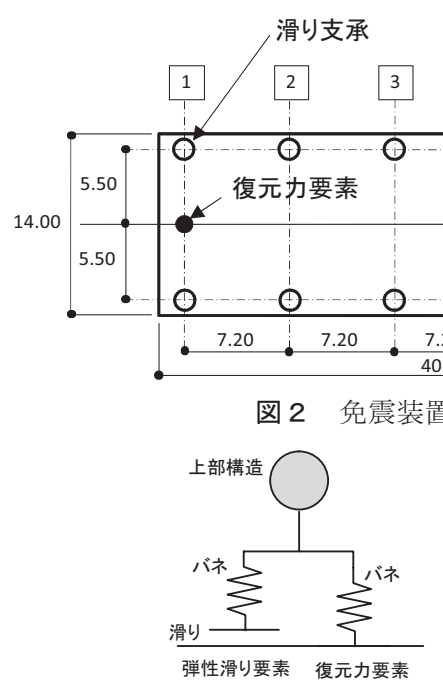

（1）弾性滑り十復元力
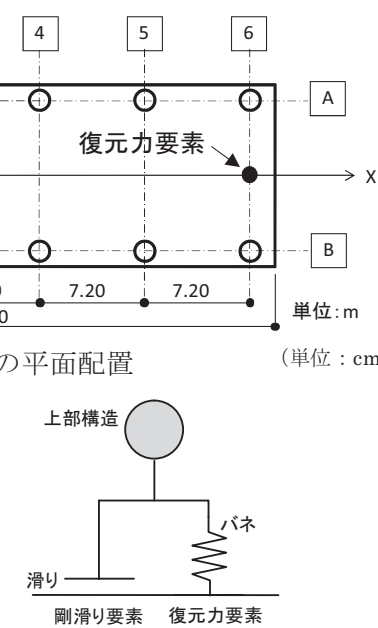

(2) 剛滑り+復元力

図 3 免震装置の概念図

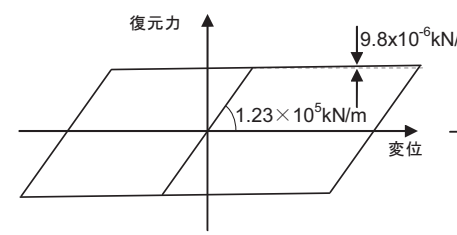

（1）弾性滑り要素モデル

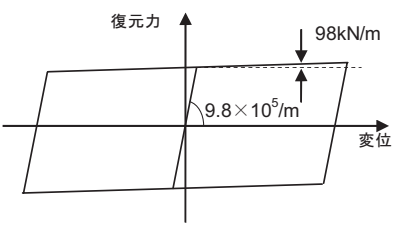

（3）中間モデル

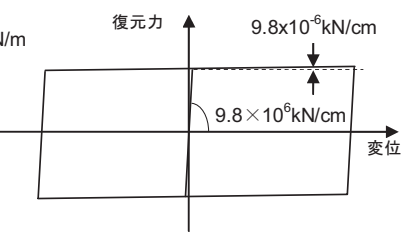

(2) 剛滑り要素モデル

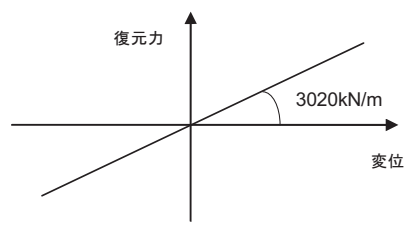

(4) 復元力要素モデル

図 4 免震装置の特性

表 2 採用した摩擦係数と対応する等価固有周期

\begin{tabular}{ccccc}
\hline & & & & $(\mathrm{s})$ \\
\hline \hline 摩擦係数 & $0.15 \mathrm{~m}$ & $0.25 \mathrm{~m}$ & $0.50 \mathrm{~m}$ & $1.00 \mathrm{~m}$ \\
\hline 0.01 & 4.9 & 5.4 & 5.8 & 6.1 \\
0.02 & 4.2 & 4.7 & 5.4 & 5.8 \\
0.05 & 3.1 & 3.7 & 4.5 & 5.2 \\
0.1 & 2.3 & 2.8 & 3.7 & 4.5 \\
0.2 & 1.7 & 2.1 & 2.8 & 3.7 \\
\hline
\end{tabular}

の積層ゴムのモデルを示す。摩擦係数は表 2 に示す 5 水準をパラメ 一タとして採用した。各摩擦係数に対する復元力要素 (4) が付い たモデルの等価周期も同じ表に示す。復元力は実際の建物の設計に おいて復元力要素である積層ゴムの限界変形が $60 \mathrm{~cm}$ であるため、 設計用の入力地震動に対して摩擦係数が 0.02 の時に応答変位がこ の範囲に収まる最も長い周期で設定した。

\section{3. 入力地震動}

解析に用いた入力地震動を表 $3-1$ 、及び表 $3-2$ に示す。残留 変形等も評価に含めるため、人工地震波は波形の平均值を 0 に揃え る等の処理がされているためここでは採用せず、全て記録地震波と した。表 3-1の地震波を基本解析波とし主たるパラメータスタデ ィーをこの地震波を用いて行った。入力地震動の最大值は最大で 3

表 3-1 使用地震波（基本解析波）

\begin{tabular}{lcccc}
\hline 入力地震波形 & $\begin{array}{c}\text { 最大加速度1 } \\
\left(\mathrm{m} / \mathrm{s}^{2}\right)\end{array}$ & $\begin{array}{c}\text { 最大加速度2 } \\
\left(\mathrm{m} / \mathrm{s}^{2}\right)\end{array}$ & $\begin{array}{c}\text { 最大加速度3 } \\
\left(\mathrm{m} / \mathrm{s}^{2}\right)\end{array}$ & $\begin{array}{c}\text { 継続時間 } \\
(\mathrm{s})\end{array}$ \\
\hline \hline El Centro 1940 NS & 3.42 & 6.83 & 10.25 & 100 \\
JMA Kobe 1995 NS & 8.18 & 16.36 & & 100 \\
Hachinohe 1968 EW & 1.81 & 3.62 & 5.43 & 120 \\
\hline
\end{tabular}

表 3-2 使用地震波（近年観測波）

\begin{tabular}{lllcc}
\hline 地震名称 & 観測点名称 & 記号 & $\begin{array}{c}\text { 最大加速度 } \\
\left(\mathrm{m} / \mathrm{s}^{2}\right)\end{array}$ & $\begin{array}{c}\text { 継続時間 } \\
(\mathrm{s})\end{array}$ \\
\hline \hline 2003年十勝沖地震 & 大樹 & HKD098 NS & 3.66 & 300 \\
& 苫小牧 & HKD129 NS & 1.73 & 300 \\
2007年新潟県中越沖地震 & 柏崎 & NIG018 NS & 6.67 & 300 \\
& 刈羽村割町新田 & $65058 \mathrm{NS}$ & 4.65 & 60 \\
& 柏崎市中央町 & $65025 \mathrm{NS}$ & 4.72 & 60 \\
\multirow{2}{*}{ 2008年宮城岩手内陸地震 } & 一関西 & INTH25 NS & 11.43 & 100 \\
& 東成瀬 & AKTH04 NS & 13.18 & 300 \\
& 鳴子 & MYG005 NS & 4.40 & 300 \\
\hline
\end{tabular}

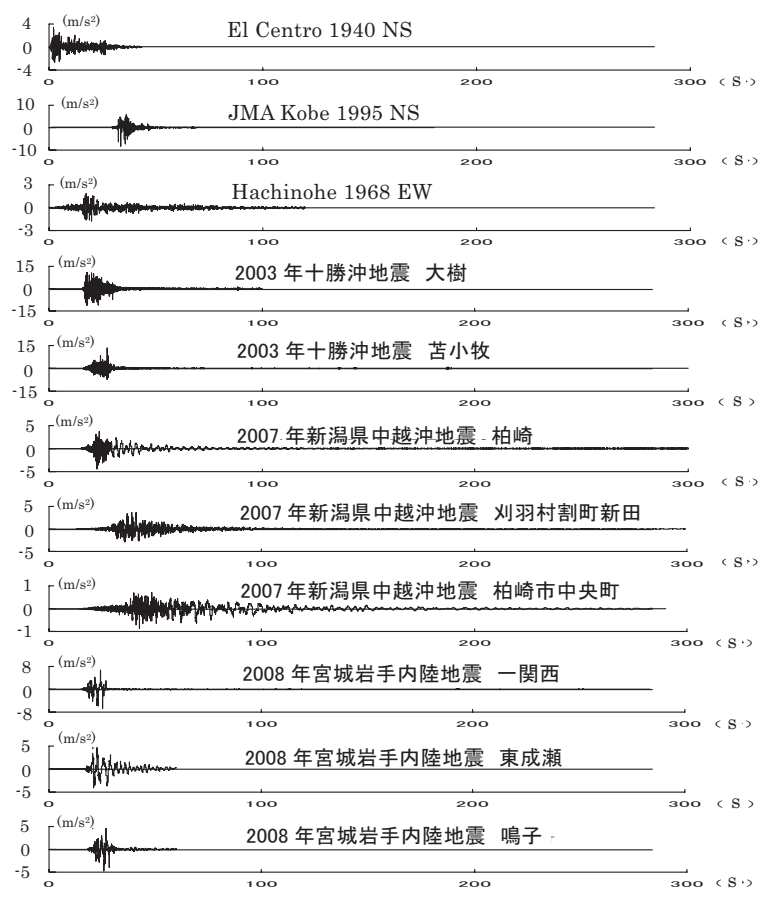

図 5 入力地震動の波形

水準用いた。また、表 $3-2$ に示す近年観測された地震動により応 答変位の評価について検討を加えた。波形を図 5 に示寸。

\section{4. 一質点応答解析結果}

図 6 に応答波形例とて El Centro $1940 \mathrm{NS} 6.83 \mathrm{~m} / \mathrm{s}^{2}$ 入力に対す る摩擦係数 0.05 における復元力付き弾性滑りにおける変位、速度、 及び加速度応答波形を示す。

図 7 に表 3-1 の地震と表 2 の条件全てに対する加速度応答解 析結果を示す。解析条件によりばらつきはあるものの、摩擦係数の 増大と共に応答加速度が上昇する。上部構造は剛体であるために、 基本的に応答加速度は摩擦係数に支配されていることが判る。

図 9 に表 $3-1$ の地震波を用いた速度応答解析結果を示す。剛 滑りで摩擦係数が大きい場合を除き、速度応答は摩擦係数によらず ほぼ一定值になる傾向を示す。摩擦係数が小さいときは最大応答速 
10

(m/5)

思加遥

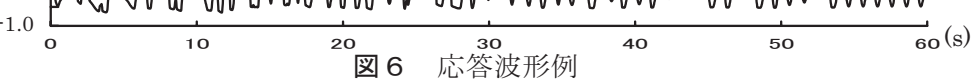

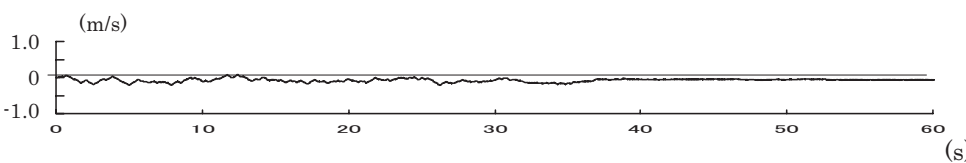

図 8 (2)式第 1 項 : $\mu=0.05 、 E 1$ Centro $6.83 \mathrm{~m} / \mathrm{s}^{2}$ 入力

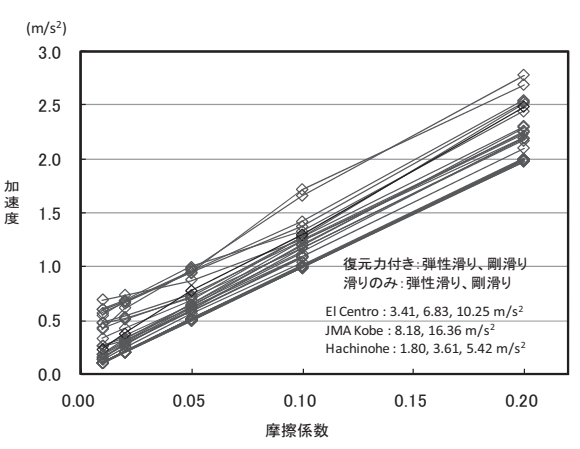

図 71 質点の最大加速度応答值

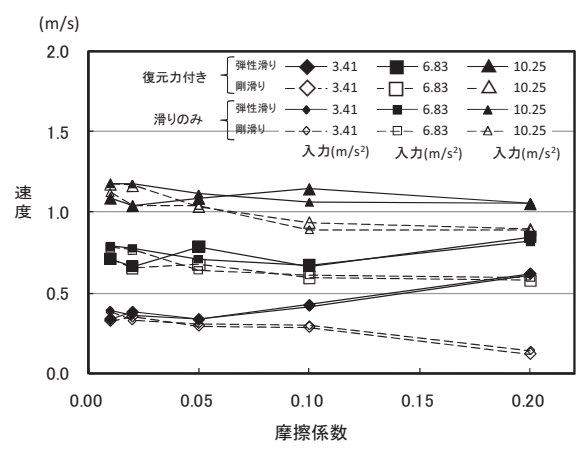

(a) El Centro $1940 \mathrm{NS}$

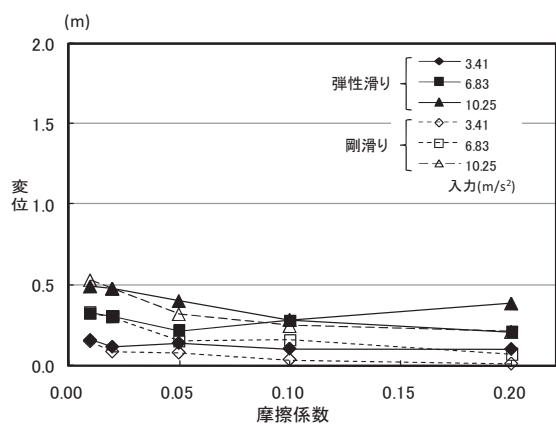

(a) El Centro $1940 \mathrm{NS}$

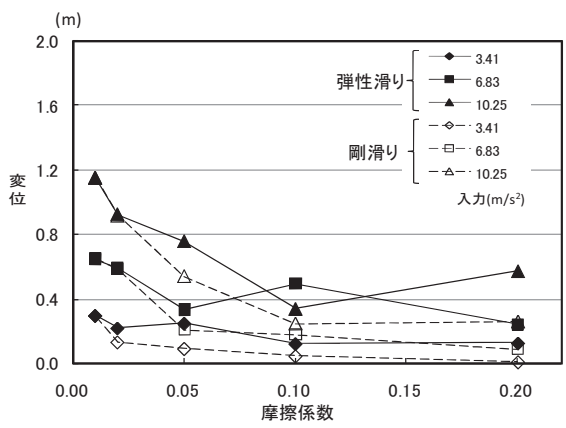

(a) El Centro 1940 NS

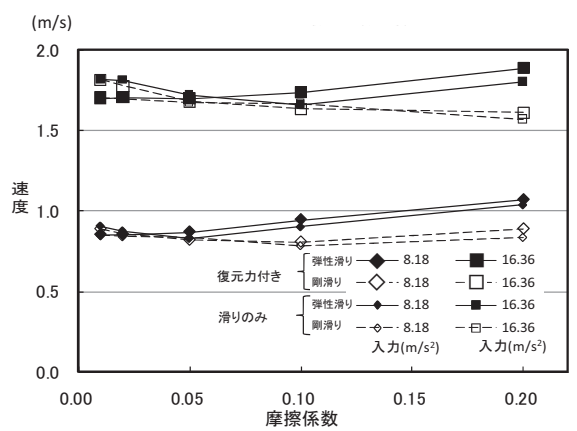

(b) JMA Kobe 1995 NS

図 91 質点の最大速度応答值

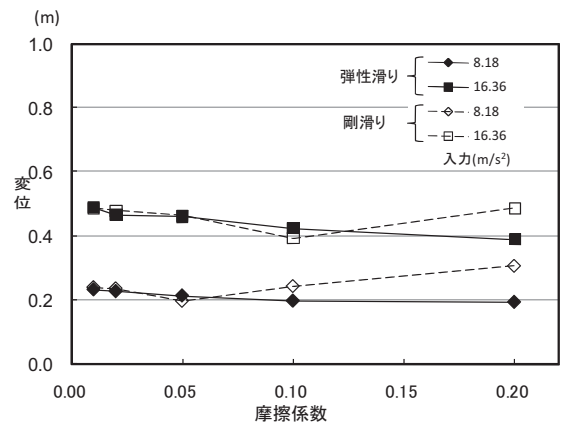

(b) JMA Kobe 1995 NS

(1) 復元力付きの応答

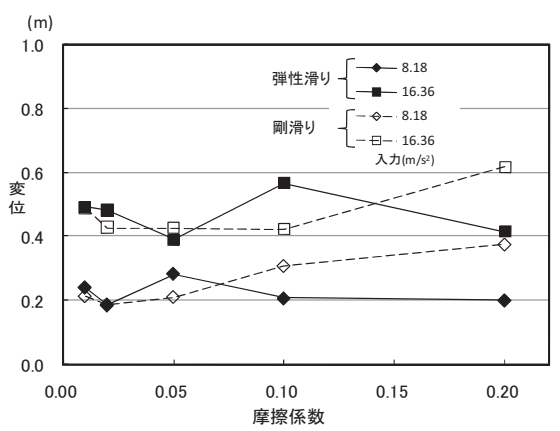

(b) JMA Kobe 1995 NS

(2) 滑りのみの応答

図 10 最大応答変位

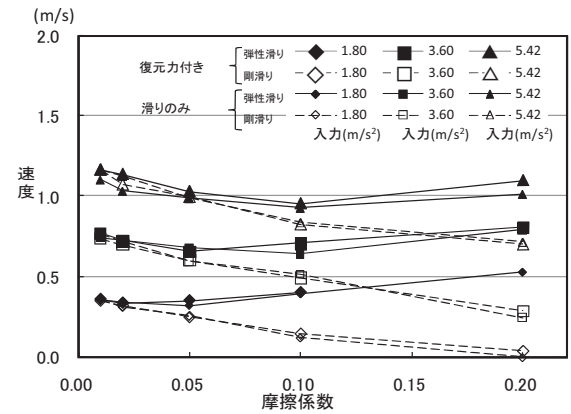

(c) Hachinohe 1968 EW

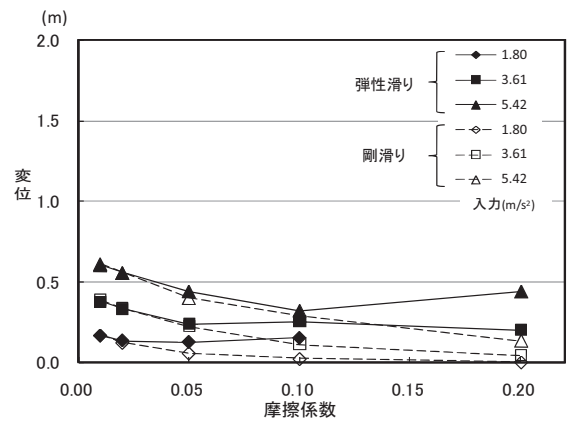

(c) Hachinohe $1968 \mathrm{EW}$

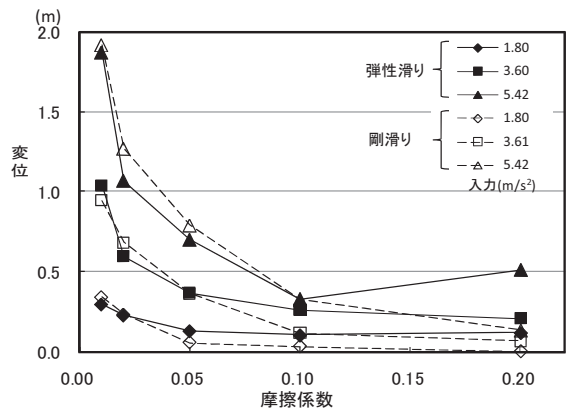

(c) Hachinohe $1968 \mathrm{EW}$ 
度は地震動の最大速度に収束している。以下に各地震波の最大速度 を示す。

$\begin{array}{ll}\text { El Centro } 1940 \text { NS } 3.42 \mathrm{~m} / \mathrm{s}^{2} & : 0.35 \mathrm{~m} / \mathrm{s} \\ \text { JMA Kobe } 1995 \text { NS } 8.18 \mathrm{~m} / \mathrm{s}^{2} & : 0.91 \mathrm{~m} / \mathrm{s} \\ \text { Hachinohe } 1968 \text { EW } 1.81 \mathrm{~m} / \mathrm{s}^{2} & : 0.34 \mathrm{~m} / \mathrm{s}\end{array}$

剛滑りの場合は地震波によっては摩擦係数の増大と共に最大応答速 度が小さくなる傾向を示している。一方、弾性滑りの場合は摩擦係 数に影響されないか、摩擦係数の増大と共に若干応答值が増大寸る 傾向を示寸。何れの場合も復元力の有無は応答值に殆ど影響を与え ていない。これは、摩擦係数が小さい場合に滑り出すと、質点側は ほぼ静止状態に近付き地面との相対速度は地面の速度が支配的とな るためと考えられる。剛滑りの場合は摩擦係数が増大寸ると地面に 引きずられている時間が長くなり相対速度は減少する。一方、弾性 滑りの場合はゴムの部分で質点が自由に動けるために、摩擦係数の 存在に拘わらず静止に近い状態が維持されるものと考えられる。

速度応答に関して簡単のため復元力のない剛滑りの運動方程式 に関して考察する。この場合の運動方程式は以下となる。

$$
(\ddot{\mathrm{x}}+\ddot{\mathrm{y}})+\mu \mathrm{g} \cdot \operatorname{sgn}(\dot{\mathrm{x}})=0
$$

全体を積分すると、以下を得る。

$$
\dot{\mathrm{x}}=-\mu \mathrm{g} \cdot \int \operatorname{sgn}(\dot{\mathrm{x}}) \mathrm{dt}-\dot{\mathrm{y}}
$$

(2)式の中の第 1 項は摩擦係数が小さい場合は第 2 項に比べて小さく、 応答速度は入力速度に近付く事が判る。ここで、 $\operatorname{sgn}(\dot{x})$ は無名数で あり、その時間による積分は時間の次元を持つ。例として El Centro $1940 \mathrm{NS} 6.83 \mathrm{~m} / \mathrm{s}^{2}$ 入力に対する摩擦係数 0.05 における(2)式の第 1 項を図 8 に示す。

図 10 に表 3 - 1 の地震波を用いた最大応答変位を示す。速度
応答と異なり、復元力の有無が最大応答值に及ぼす影響は顕著であ る。また、摩擦係数の増大に伴い最大応答変位は小さくなる傾向が 見られる。但し、JMA Kobe の場合は復元力の影響が見えにくく、 摩擦係数の違いによる応答量の差も明確ではない。これは地震波の 主要動の継続時間によるものと考えられる。弾性滑りと剛滑りの差 は何れも小さい。

図 11 に残留変位を示す。摩擦係数の大きさと残留変位量の関 係は殆ど見られない。その一方で、復元力の有無が及ぼす影響は顕 著である。中間モデルでは復元力部材に相当する降伏後の 2 次勾配 が僅かしかないにも拘わらず、完全な剛滑りと比心゙ると残留変位は 非常に小さい。また、滑りのみの場合では弾性滑りより剛滑りは若 干残留変位が小さくなる。

図 12 に表 $3-2$ に示す近年観測された地震波を用いた剛滑り を用いた場合の最大応答変位を示寸。一つのグラフ内には同じ地震 における異なった観測地点での記録を用いた解析結果を合わせて示 す。 2007 年刈羽村割町新田の記録では摩擦係数が $0.01 、 0.02$ の場 合応答值が非常に大きくなり図中に示していない。2008 年東成瀬以 外は摩擦係数の増大に応じて最大応答変位は小さくなる傾向が判る。

しかし、El Centro 1940 NS、Hachinohe 1968 EW に比心゙、復 元力の有無が最大応答変位を抑制する効果は低く、地震波によって はむしろ逆の場合もある。何れの場合も地震波に含まれる長周期成 分が最大応答変位に大きく影響すると考えられる。

図 13 に表 $3-2$ の地震波を用いた場合の残留変形を示す。図 11 と異なり、摩擦係数の大きさが残留変位を抑制する傾向が見ら れる。また、復元力の有無は表 $3-1$ の地震波の場合同様残留変位 の抑止に効果的に働く事が判る。

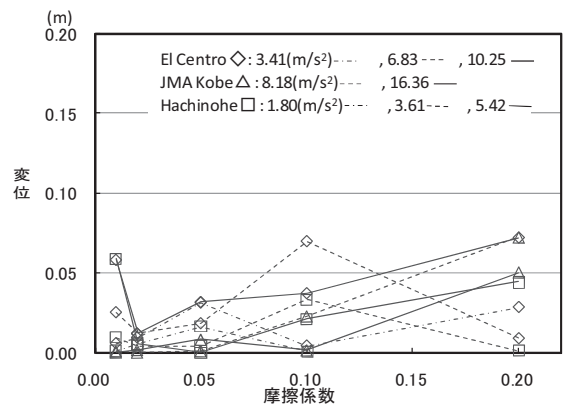

（1）復元力付き 弾性滑り

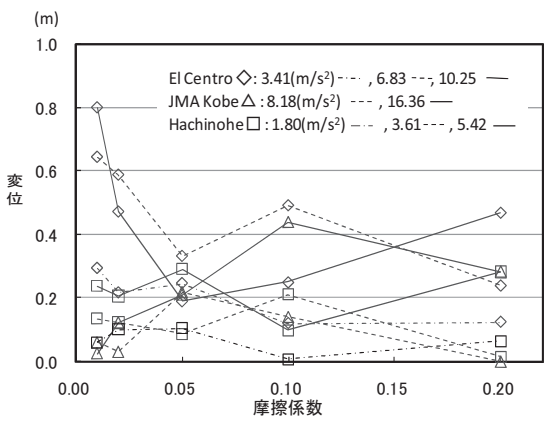

（3）滑りのみ 弾性滑り

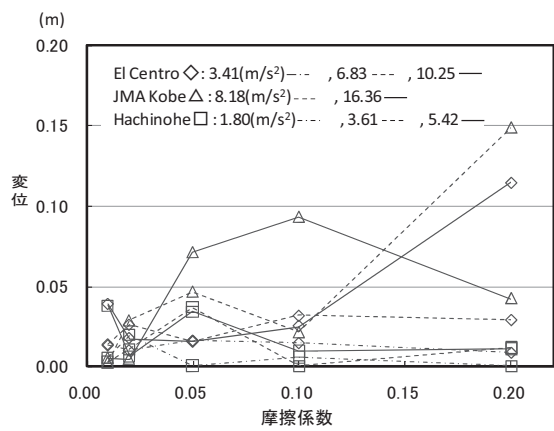

（2）復元力付き 剛滑り
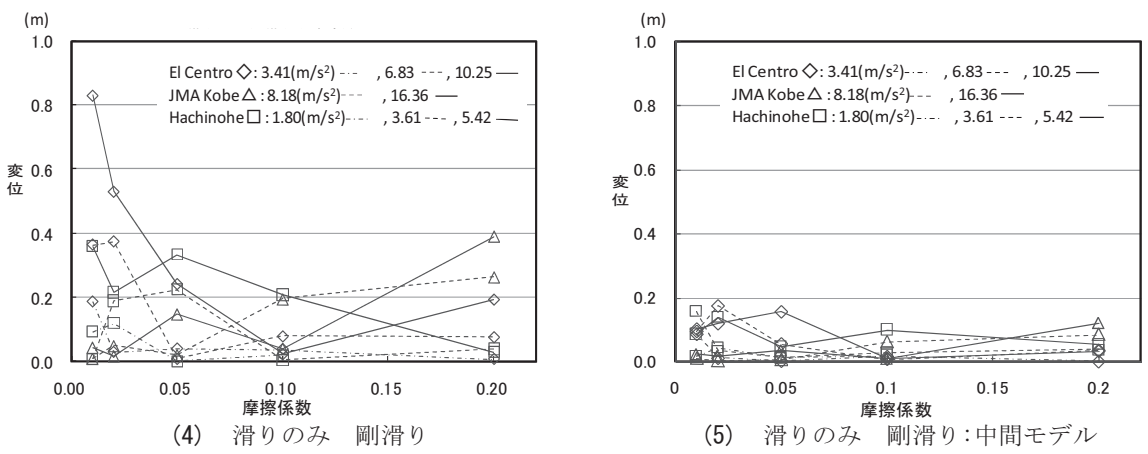

（5）滑りのみ 剛滑り:中間モデル

図 11 残留変位 


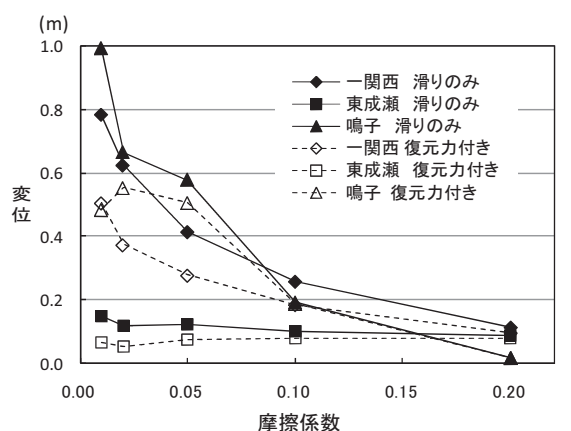

(a) 2008 年 宮城岩手内陸地震

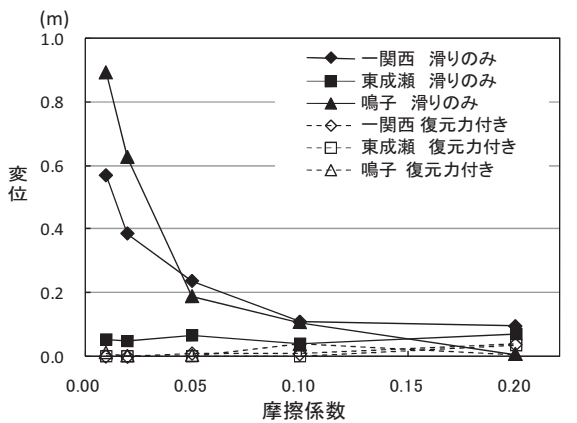

（a） 2008 年 宮城岩手内陸地震

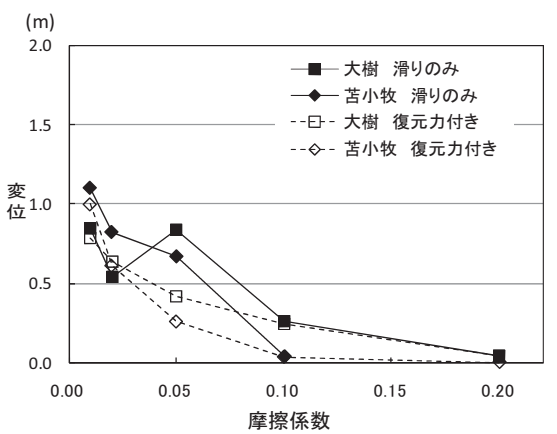

(b) 2003 年 十勝沖地震

図 12 近年観測波による最大応答変位

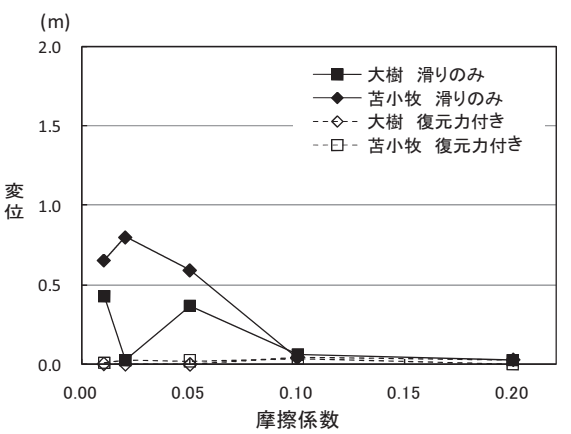

(b) 2003 年 十勝沖地震

図 13 近年観測波による残留変位

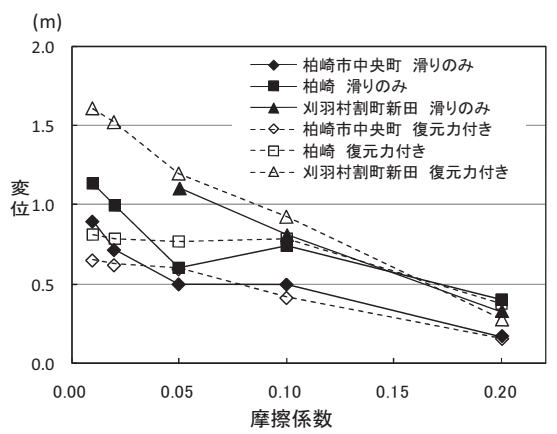

(c) 2007 年 新潟県中越沖地震

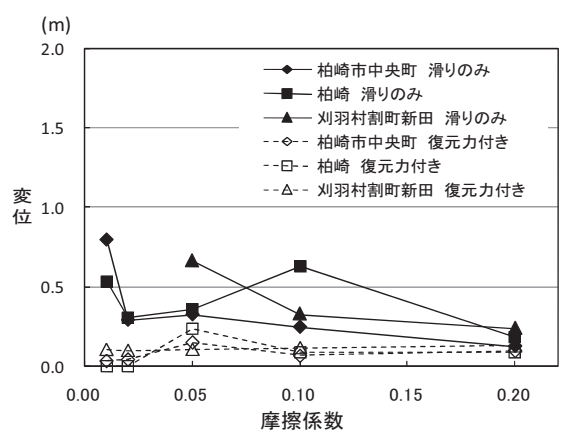

（c） 2007 年 新潟県中越沖地震

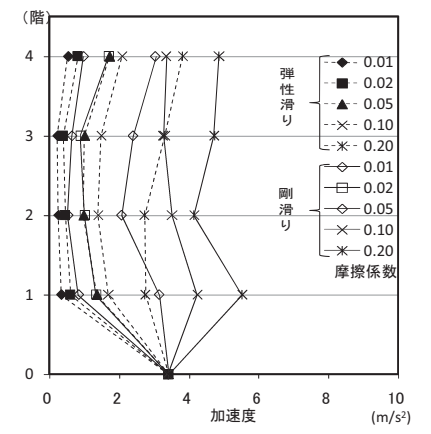

(1) $3.42 \mathrm{~m} / \mathrm{s}^{2}$ 入力

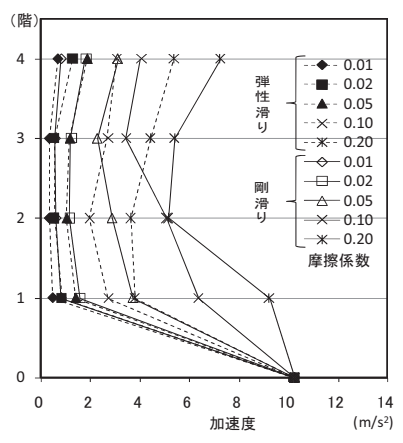

(2) $10.25 \mathrm{~m} / \mathrm{s}^{2}$ 入力

図 14 多質点最大応答加速度

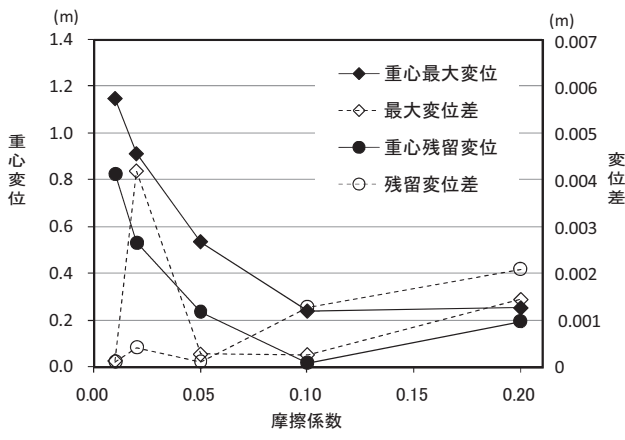

（1）剛滑り $\pm 10 \%$ 差

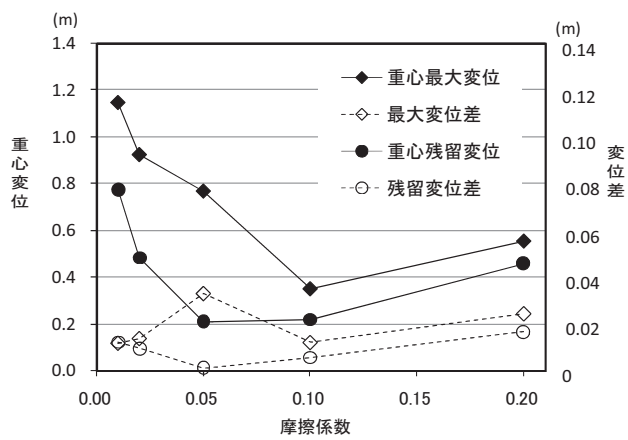

（3）弾性滑り $\pm 10 \%$ 差

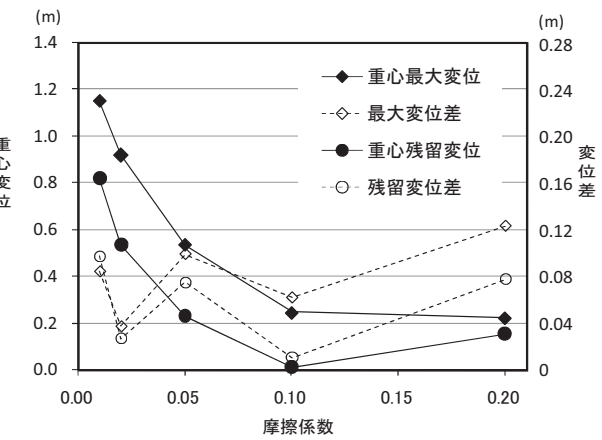

（2）剛滑り $\pm 50 \%$ 差

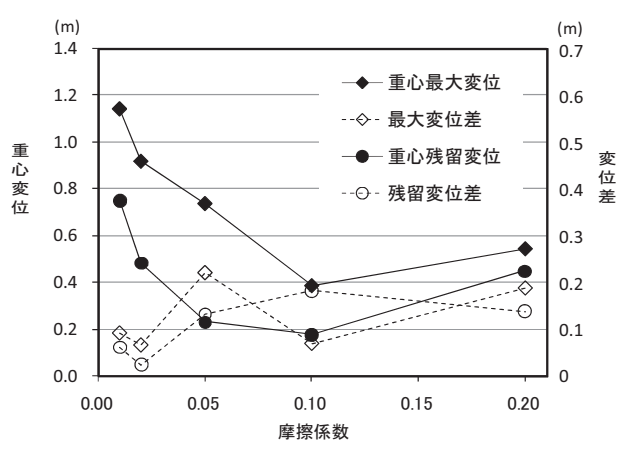

（4）弾性滑り $\pm 50 \%$ 差

図 15 剛体㨝れ応答 


\section{5. 多質点応答解析結果}

入力レベルと摩擦係数が上部構造の応答に及ぼす影響を見るた めに上部架構は 4 質点の串団子で、復元力の無い滑りのみの免震モ デルを用いた応答解析による最大加速度応答結果を図 14 に示寸。 入力は全て El Centro1940 NS を用い $3.41 \mathrm{~m} / \mathrm{s}^{2}$ の入力と $10.25 \mathrm{~m} / \mathrm{s}^{2}$ 入力の場合、及び剛滑りと弾性滑りの場合を比較した。一部の応答 解析において、上部構造は第 1 折れ点即ちひび割れは発生したが、 第 2 折れ点を超えたケースはなく、 $\mathrm{RC}$ 構造として弾性と呼べる範 囲の応答にとどまった。弾性滑りにした場合は上部構造の加速度応 答を何れの入力の場合も効果的に抑制している。但し、 $3.41 \mathrm{~m} / \mathrm{s}^{2}$ 入 力における摩擦係数 0.2 の場合では加速度は低減されていない。し かし、増幅もないので免震効果を発揮しているといえる。一方剛滑 りの場合は $3.41 \mathrm{~m} / \mathrm{s}^{2}$ 入力における摩擦係数 $0.1 、 0.2$ の場合では応 答加速度は若干増幅傾向にある。本解析モデルは免震構造の特長を 生かし、上部構造を若干柔らかめに設計しているために通常より上 部構造における加速度応答は大きめに出ており、剛滑りを用いた場 合、摩擦係数は概ね $0.05 \sim 0.1$ 以下に抑える必要がある。

\section{6. 㧖れ応答解析結果}

剛床を仮定した水平 2 方向、及び㧖れの 3 自由度解析解析によ り㧖れ応答評価を行う。上部構造を剛体 1 質点とし免震装置の平面 配置を図 2 とした。滑り支承、及び積層ゴムの特性はマルチスプリ ングとし、x 軸方向を基点として反時計回りに $0^{\circ} 、 45^{\circ} 、 90^{\circ}$ 、 $135^{\circ}$ の各方向に 1 軸の $1 / 2$ の初期剛性を持たせた。また滑り支承 の降伏耐力、即ち摩擦係数が $1 / \sqrt{2}$ となる履歴バネを配置した。滑り 支承は剛滑り、及び弾性滑りとした。上部構造は質量が $14.00 \mathrm{~m} \times$ $40.00 \mathrm{~m}$ の平面に一様に分布しているとし、上部構造の回転慣性を $4.65 \times 10^{8} \mathrm{~kg} \cdot \mathrm{m}^{2}$ とした。

滑り支承の摩擦係数のバラツキが㧖れ応答にどの様に影響する かを見るために、 1 通りと 6 通りの滑り支承を、基準值に対してそ れぞれ $-10 \%$ と $+10 \%$ 、及び $-50 \%$ と+50\%と変化させた場合の応答解 析を行った。入力は El Centro $1940 \mathrm{NS} 6.83 \mathrm{~m} / \mathrm{s}^{2}$ を y 方向に入力し た。

図 15 に解析結果を示す。基準值に対して- $10 \%$ と+10\%の摩擦 係数の差に対して、 $40.00 \mathrm{~m}$ の建物長辺に対し剛滑りでは最大 $0.004 \mathrm{~m}$ の変位差、弾性滑りでも最大 $0.04 \mathrm{~m}$ 変位差であり、重心位 置における最大変位と残留変位の大きさに比べ、非常に小さい。摩 擦係数が大きい $0.1 \sim 0.2$ の場合に対しては最大変位と残留変位に 対して約 $1 / 10$ の㧖れ量となった。基準值に対して-50\%と $+50 \%$ の非常に大きな摩擦係数の差においても、剛滑りで最大 $0.12 \mathrm{~m} 、$ 弾 性滑りで最大 $0.20 \mathrm{~m}$ の変位差に留まった。摩擦係数が大きい 0.1 0.2 の場合に対しては最大変位と残留変位に対して約 $1 / 2$ の捩れ 量となった。また、剛滑りと弾性滑りでは剛滑りの時に㨝れ応答量 が小さい事が判る。

\section{7. 結論}

以上の検討結果から、結論を以下にまとめる。

1 ) 本検討では最大応答変位、残留変位共に、復元力要素の有無に 大きく影響される結果を得た。特に残留変位は僅かでも復元力 があると十分小さく押さえることができる事が判った。しかし、
地震波によっては復元力の有無は最大変位の抑止にはあまり 効果がない場合があった。この原因についての分析は別の論文 に譲るが、長周期成分や入力の偏り等の影響は無視し得ないと 考えられる。これらは地震計の傾きによる場合なども含まれる と考えられるが、入力地震動の精度に関する問題は本論の趣旨 を超えるため、ここでは議論の対象としない。総合的には例え 非常に小さな物でも、何らかの復元力を付与寸ることは免震構 造のロバスト性を高めることに貢献すると考えられる。

2 ) 復元力要素がなく摩擦係数が非常に小さい場合 $(\mu=0.02$ 以下)、 応答変位は $1 \mathrm{~m}$ 以上に及ぶケースがあった。しかし、 $\mu=0.05$ 以上では大入力に対しても過大にならない様押さえることが 可能である。本検討で用いた入力では $1 \mathrm{~m}$ 以内に収まった。即 ち、復元力が全くない場合でも、ある程度大きな摩擦係数を採 用することが免震構造のロバスト性を高めることに貢献する と考えられる。

3 ）上部架構の応答低減に対し、滑り支承は入力が大きくなるほど 有利に作用寸る。弾性滑り支承の場合は $3.00 \mathrm{~m} / \mathrm{s}^{2}$ 程度の入力に 対しても十分免震効果が期待できる。剛滑りの場合でも $\mu$ $=0.05$ 以下の摩擦係数を採用寸ればある程度小さな入力レベル に対しても加速度低減効果が期待できる。

4 ）滑り支承の平面配置における摩擦係数のばらつきに対し、据れ 応答は鈍感である事が判った。本検討では土 $10 \%$ 程度のばらつ きであれば、並進応答に対し㧖れ応答は殆ど無視できる程度で あった。この意味で滑り支承は性能のばらつきに対して圥長性 がある免震装置であると考えられる。

滑り支承による免震構造は入力の増大に対し、上部構造の応答を十 分に小さく抑える性能を有している。本検討により、応答変位には かなりの余裕を必要とするが、摩擦係数を 0.05 から 0.1 の範囲にと れば応答変位と残留変位はある範囲内に制御することが期待でき る。従って、設計時の入力を上回る大きな地震に対しても、免震層 における $\mathrm{P}-\Delta$ 効果があまり問題にならないよう基礎梁に十分な剛 性を持たせ、滑り支承を採用し大変形を許容寸る事により、かなり の圥長性を持たせる事が可能であると考えられる。即ち、原子力発 電所等の大規模で敷地に余裕があり、かつ厚いマットスラブを有す る構造物等にロバスト性を付与するには有効な手段の一つと考え られる。

\section{参考文献}

1 ）和田章、王竹：「不慮の部材破壊による不静定服装立体卜ラスの耐力低下 に関する研究」、日本建築学会構造系論文集、第 402 号、pp. 121-131、 1989.8

2 ) 伊山潤、桑村仁 :「地震に対するフェールセーフ構造」、日本建築学会構 造系論文集、第 507 号、pp. 29-34、1998.5

3 ) 伊藤拓海、大井謙一、李正林：「鉛直荷重を受ける骨組夕構造物の几長性 に関わる感度解析」、日本建築学会構造系論文集、第 593 号、pp. 145-151、 2005.7

4 ) 藤田聡、岡村茂樹：「すべり型免震装置の地震時挙動（その 1 : 研究の背 景と目的) 」、[No.991-2] 日本機械学会東北支部 米沢地方講演会講演論文 集、pp. 43-44、1999.9

5 ) Hamaguchi, H., Higashino, M., et al: "Development of Low friction factor sliding isolation device", 12WCEE, 2135/6/A, 2000

6 ) Higashino, M., Hamaguchi, H., et al: "Basic Characteristics and Durability of Low-Friction Sliding Bearing for Base Isolation”, Earthquake Engineering and Engineering Seismology, Vol. 4, No. 1, pp. 
95-105, September 2003

7 ) Bowden, F. P. and Tabor, D.: "The Friction and Lubrication of Solids", Clarendon Press, Oxford

8 ）深堀美英：「設計のための高分子の力学」、技報堂出版、2000.10

9 ）稲井慎介、大川出、他：「滑り支承を用いた免震建物の振動台実験 その 6、固着実験とシミュレーション解析」、日本建築学会大会学術講演梗概 集（関東）B-2 構造 II、21300、pp. 599-600、2006.9

$10 ）$ 沢辺浩、栗田哲、杉村義広：「剛滑り支承免震建物の地震応答解析法に 関する基礎的研究」、第 11 回日本地震工学シンポジウム、313、pp. 1689-1694、2002

11 ) 中村満喜男：「滑り支承を有する免震建物の応答解析に関する研究」、 日本建築学会大会学術講演梗概集（東海） B-2 構造 II、21224、pp 447-448、2003.9

12 ) I. D. Aiken and J. M. Kelly, "Earthquake simulator testing and analytical studies of two energy absorbing systems of multistory structure", Report No. UCB/EERC-90/03, Earthquake Engineering Research Center, University of California, Berkeley, CA, 1990

13 ）千葉陽一、薩川恵一、北村春行、小山慶樹：「低摩擦型す心゙り支承と積 層ゴム・ダンパーを組み合わせた免震構造のエネルギーの釣合に基づく 応答予測法」、日本建築学会構造系論文集、第 575 号、pp. 65-72、2004.1

14 ）遠山幸太郎、相沢覚：「す心゙り免震構造の残留変位に関する一考察」、 日本建築学会大会学術講演梗概集（東北） B-2 構造 II、21328、2000.9

15 ）日比野浩、久保哲夫、高木正美、勝田庄二：「弾性滑り支承と積層ゴム を併用した複合免震建物の地震応答性状」、日本建築学会構造系論文集、 第 593 号、pp. 43-50、2005.7

16 ）原誠、畑中公樹、他：「立体架構弾塑性応答統合システム 「HYPER-DYNAMICS」の開発」、日本建築学会・情報システム技術委 員会 第 16 回情報システム利用技術シンポジウム、 pp. 97-102、1993

17 ) I. Takewaki, "Robustness of base-isolated high-rise buildings under code-specified ground motions", Struct. Design Tall Spec. Build. 17, pp. 257-271, 2008

18 ）小出敏弘、永井潔、宇野哲生、高井秀博：「免震構法実用化に関する研 究 (その 4) 摩擦ダンパーのトリガーレベルに関する解析的検討」、日本
建築学会大会学術講演梗概集（近畿）B 構造 I、2424、pp847-848、1987

\section{付録}

剛滑り支承を用い復元力がない場合に対して初期剛性（=除荷剛性）が応答 值に与える影響を宮城岩手内陸地震鳴子 $4.40 \mathrm{~m} / \mathrm{s}^{2}$ に対し、残留変位、最大応 答変位、及び最大応答速度について付図 1 〜 3 にそれぞれ示す。初期剛性が $1.0 \times 10^{6} \mathrm{kN} / \mathrm{m}$ 以下ではその值により応答值は変化するが、 $1.0 \times 10^{7} \mathrm{kN} / \mathrm{m}$ 以 上では応答值はほぼ一定の值になっている。この傾向は摩擦係数によらず安 定しているといえる。本論では $9.8 \times 10^{6} \mathrm{kN} / \mathrm{m}$ を初期剛性として採用した。

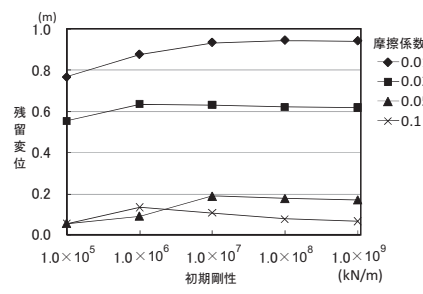

付図 1 初期剛性と残留変位の関係

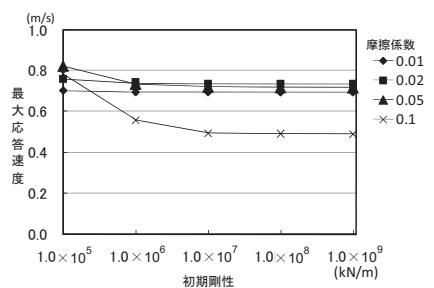

付図 3 初期剛性と最大応答速度の関係

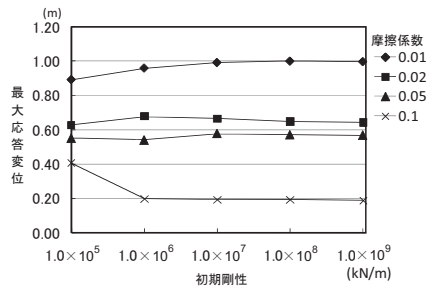

付図 2 初期剛性と最大応答変位の関係

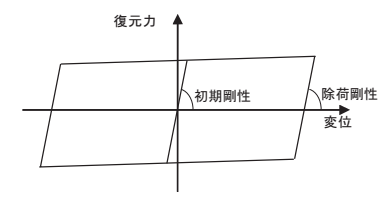

凡例
（2008年11月10日原稿受理，2009年 3 月23日採用決定） 